\title{
PENGARUH TEMPERATUR TERHADAP PERKEMBANGAN NEMATODA SISTA KENTANG (GLOBODERA SPP.) INDONESIA
}

\author{
Lisnawita $^{1}$, Meity S. Sinaga ${ }^{2}$, Supramana ${ }^{2}$ \& Gede Suastika ${ }^{2}$
}

\begin{abstract}
The effect of temperature on the development of Indonesian potato cyst nematode. Potato cyst nematode (PCN) is a serious pathogen of potato and is found in most potato producing areas of the world. In Indonesia, PCN was recently discovered and recognized as major constraint on potato. The growth and behaviour of nematodes are affected by the environment. Therefore, determination of the biology of PCN Indonesian populations is urgently needed to manage this pathogens effectively. The effect of temperature on biology factors of four PCN Indonesian populations (North Java 1, North Java 2, West Java, and Central Java) was studied at different temperatures levels $\left(12,15,18,21\right.$ and $\left.24^{\circ} \mathrm{C}\right)$ in the growth chamber. The aim of this research was to study the effect of temperature on development of PCN. Observation was conducted on cyst number, reproduction factor (Rf), survival, fecundity and multiplication of PCN. The optimum temperature range for maximum cysts production with the highest reproduction factor, survival, fecundity and multiplication rate for all populations was $15-21^{\circ} \mathrm{C}$. The hatching and development of all $\mathrm{PCN}$ populations reduced at temperature below $15^{\circ} \mathrm{C}$ or above $21^{\circ} \mathrm{C}$.
\end{abstract}

Key words: Indonesian potato cyst nematode, number of cysts, reproduction factor, survival, fecundity

\section{PENDAHULUAN}

Nematoda sista kentang (NSK), Globodera rostochiensis dan G. pallida merupakan nematoda parasit terpenting pada tanaman kentang (Jensen et al., 1979). Saat ini NSK telah tersebar di banyak negara subtropika dan tropika yang berudara sejuk. Kondisi lingkungan yang sesuai untuk pertumbuhan kentang, akan sesuai juga untuk hidup dan perkembangan NSK.

Seperti nematoda parasit tumbuhan lainnya, faktor lingkungan seperti temperatur, kelembaban, aerasi dan jenis tanah mempengaruhi perkembangan NSK. Di antara faktor lingkungan tersebut, temperatur merupakan faktor abiotik yang paling penting. Nematoda sista kentang mempunyai temperatur optimum untuk metabolisme, pertumbuhan dan aktivitasnya (Vannier, 1994). Di samping itu temperatur juga mempengaruhi dormansi (diapause) (Huang \& Pereira, 1994), siklus hidup, daya tahan hidup (survival) dan perilaku (behaviour) NSK (Wharton et al., 2002). Peningkatan atau penurunan temperatur dari temperatur optimum, menyebabkan laju metabolisme dan aktivitas nematoda menjadi lambat (Vannier, 1994).
Beberapa penelitian tentang pengaruh temperatur terhadap aktivitas NSK telah dilakukan. Mc Kenna \& Winslow (1972) mendapatkan bahwa pada temperatur $25^{\circ} \mathrm{C}$ juvenil G. rostochiensis menetas lebih cepat dibandingkan G. pallida. Ellis \& Hesling (1975) telah menguji 20 isolat G. rostochiensis dan G. pallida pada temperatur $18^{\circ} \mathrm{C}$, dan hasil penelitiannya menunjukkan bahwa G. pallida menetas lebih cepat daripada G. rostochiensis. Stone \& Webley (1975) mendapatkan bahwa pada temperatur yang tinggi, sista G. pallida lebih sensitif dibandingkan dengan $G$. rostochiensis.

Informasi tentang pengaruh temperatur terhadap G. rostochiensis dan G. pallida di Indonesia belum pernah dilaporkan, padahal infomasi ini penting untuk mengetahui temperatur optimum yang mempengaruhi perkembangan NSK di Indonesia, mengingat nematoda ini telah tersebar luas di Jawa Tengah dan Jawa Barat (Daryanto, 2003; Lisnawita et al., 2005).

Berdasarkan uraian di atas, penelitian ini dilakukan untuk mengetahui pengaruh temperatur terhadap perkembangan NSK di Indonesia.

\footnotetext{
${ }^{1}$ Departemen Hama dan Penyakit Tumbuhan, Fakultas Pertanian, Universitas Sumatera Utara, Jl. Prof. A. Sofian No. 3 Medan 20155. E-mail: itamuis@yahoo.com

${ }^{2}$ Departemen Proteksi Tanaman, Fakultas Pertanian, Institut Pertanian Bogor,

Jl. Kamper Kampus Darmaga, Bogor 16680
} 


\section{METODE PENELITIAN}

Penelitian dilaksanakan di Laboratorium Nematologi dan Laboratorium Pengendalian Hayati Departemen Proteksi Tanaman, Institut Pertanian Bogor, dari September 2006 sampai Januari 2007.

Persiapan Tanaman Inang. Tanaman inang, yaitu kentang kultivar Desiree diperbanyak secara kultur jaringan dengan menggunakan media Murashige \& Skoog (MS0). Setelah berumur 2 minggu, planlet diaklimatisasi dengan memindahkannya ke dalam pot plastik (diameter $5 \mathrm{~cm}$ dan tinggi $9 \mathrm{~cm}$ ). Media tanam yang digunakan adalah tanah : arang sekam steril $(\mathrm{v} / \mathrm{v}=$ 1:1). Untuk membantu pertumbuhan, tanaman dipupuk sebanyak dua kali, yaitu 7 dan 30 hari setelah aklimatisasi, masing-masing dengan $0,25 \mathrm{~g}$ Urea per pot. Untuk mendapatkan pertumbuhan akar yang relatif seragam, delapan hari sebelum diinokulasi, semua tanaman uji di tempatkan dalam growth chamber pada temperatur $18^{\circ} \mathrm{C}$ (Foot, 1977).

Populasi Nematoda Sista Kentang. Sista dari keempat isolat yaitu Jawa Timur 1 (S1), Jawa Timur 2 (S2), Jawa Barat (S3) dan Jawa Tengah (S4) dikumpulkan dari perbanyakan NSK di laboratorium dengan mengekstraksi tanah menggunakan metode Sheperd (1985). Sepuluh sista NSK yang diambil secara acak diinokulasi pada setiap tanaman dengan cara memasukkan sista ke dalam kantong kassa yang berukuran $2 \times 2 \mathrm{~cm}^{2}$, kemudian kantong kassa diletakkan di sekitar akar (Foot, 1978; Franco, 1979). Tanaman dibiarkan di dalam growth chamber pada temperatur $12^{\circ} \mathrm{C}, 15^{\circ} \mathrm{C}, 18^{\circ} \mathrm{C}, 21^{\circ} \mathrm{C}$ dan $24^{\circ} \mathrm{C}$ dengan kelembaban relatif $(\mathrm{RH}) 80 \%$, pencahayaan dengan 12 jam terang dan 12 jam gelap selama 56 hari.

Rancangan Percobaan. Penelitian menggunakan Rancangan Acak Lengkap (RAL) faktorial, yang terdiri dari dua faktor dengan 5 ulangan. Faktor pertama yaitu perlakuan isolat (S) dan faktor kedua adalah temperatur (T). Perlakukan isolat terdiri atas empat taraf, yaitu : S1, S2, S3 dan S4. Perlakuan temperatur terdiri atas 5 taraf temperatur yang berbeda, yaitu : $\mathrm{T} 1=12^{\circ} \mathrm{C}, \mathrm{T} 2=$ $15^{\circ} \mathrm{C}, \mathrm{T} 3=18^{\circ} \mathrm{C}, \mathrm{T} 4=21^{\circ} \mathrm{C}$ dan $\mathrm{T} 5=24^{\circ} \mathrm{C}$ dengan kelembaban relatif (RH) 80\%, pencahayaan dengan 12 jam terang dan 12 jam gelap selama 56 hari. Kombinasi perlakuan adalah $4 \times 5=20$ dan total tanaman yang digunakan adalah $20 \times 5=100$ tanaman. Untuk mengetahui pengaruh perlakuan dilakukan analisis ortogonal polinomial dan analisis korelasi antar variabel (Mattjik \& Sumertajaya, 2000).

Pengamatan. Pengamatan dilakukan 56 hari setelah inokulasi (hsi) dengan cara mengeluarkan tanaman dari pot. Tanah dan akar diekstraksi dengan metode Sheperd (1985). Pengamatan dilakukan terhadap : (a) jumlah sista baru, yaitu sista yang terdapat di luar kantong kassa pada akhir pengamatan, (b) faktor reproduksi (Rf), yaitu perbandingan jumlah sista pada akhir penelitian (Pf) dengan jumlah sista pada awal penelitian (Pi), (c) daya tahan hidup, yaitu jumlah sista baru dibandingkan dengan jumlah telur dalam sista baru, (d) keperidian, yaitu jumlah telur (dihitung dengan memecahkan sista) dibandingkan dengan jumlah sista baru, dan (e) perbanyakan nematoda, yaitu perkalian antara kemampuan bertahan hidup dengan keperidian.

\section{HASIL DAN PEMBAHASAN}

Temperatur merupakan faktor abiotik yang secara langsung mempengaruhi perkembangan dan pertumbuhan nematoda (Ferris et al., 1996; Gao \& Becker, 2002; Noe, 1991). Hal ini dapat dilihat pada Gambar 1, 2, dan 3 dimana temperatur mempengaruhi faktor-faktor biologi yang diamati yaitu : jumlah sista baru, Rf, daya tahan hidup, keperidian dan perbanyakan NSK dari setiap isolat yang digunakan. Masing-masing isolat mempunyai persamaan kuadratik dengan temperatur optimum antara $15-21^{\circ} \mathrm{C}$. Jumlah sista baru, faktor reproduksi, daya tahan hidup, keperidian dan perbanyakan akan mengalami penurunan pada temperatur di bawah $15^{\circ} \mathrm{C}$ atau di atas $21^{\circ} \mathrm{C}$.

Dari Gambar 1, 2, dan 3 juga terlihat nilai tertinggi untuk semua peubah pengamatan terdapat pada isolat S3 yang kemudian diikuti dengan S2, S1 dan yang terendah adalah $\mathrm{S} 4$. Hal ini dapat terjadi karena isolat S3, S2, dan S1 merupakan spesies G. rostochiensis sedangkan S4 merupakan populasi campuran (G. rostochiensis dan G. pallida) (Lisnawita et al., 2005). Mulder (1988) melaporkan temperatur optimum untuk perbanyakan dan penetasan $G$. rostochiensis adalah mendekati $20^{\circ} \mathrm{C}$, dan proses ini akan menurun drastis pada temperatur di bawah $10^{\circ} \mathrm{C}$ dan di atas $27^{\circ} \mathrm{C}$.

Hasil yang sama dilaporkan oleh Castillo \& Vovlas (2002) bahwa temperatur optimum untuk penetasan telur Heterodera mediterranea pada tanaman zaitun adalah $20-25^{\circ} \mathrm{C}$. Sedangkan G. pallida mempunyai temperatur 

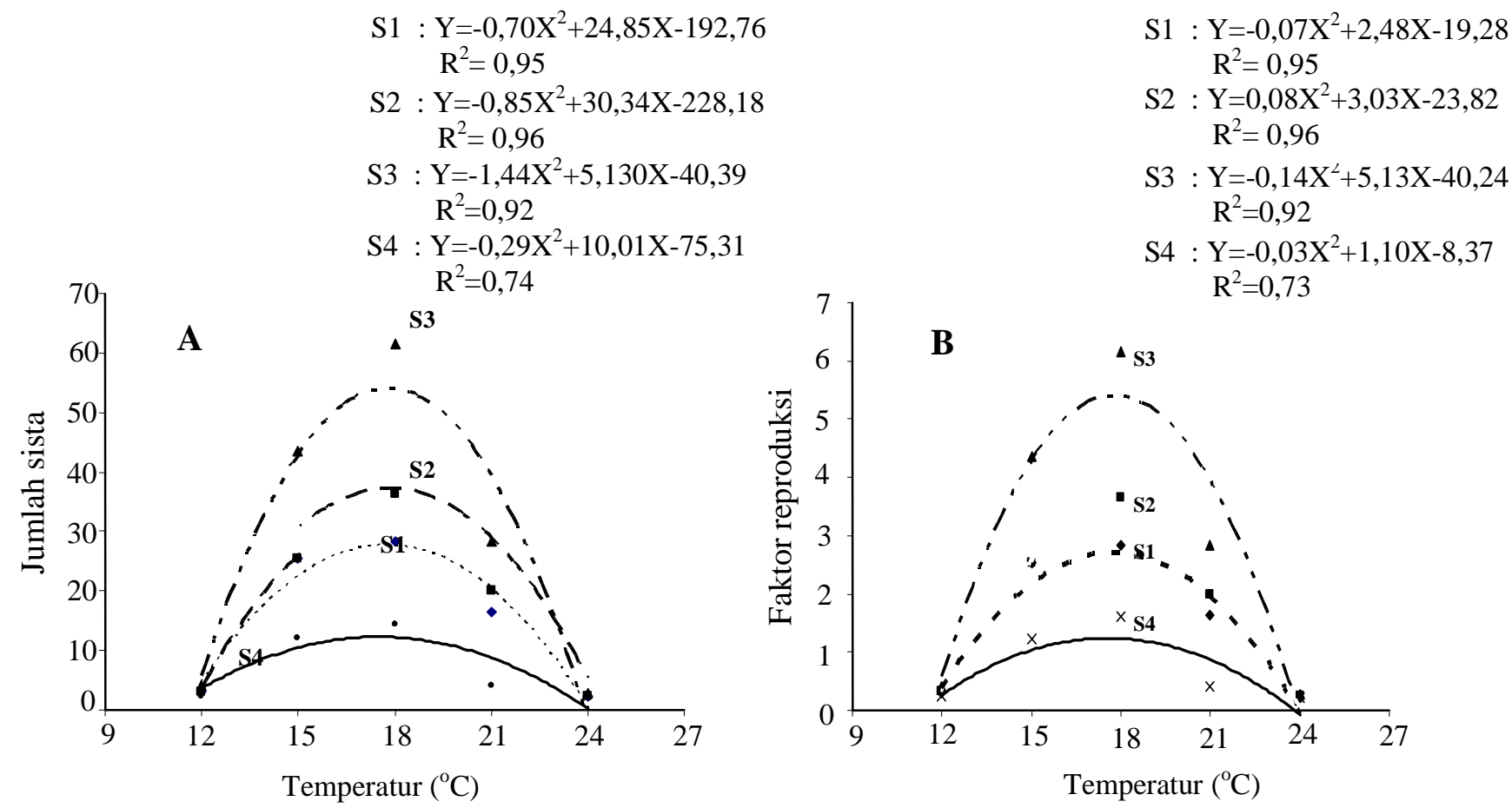

Gambar 1. Pengaruh temperatur terhadap jumlah sista (A) dan faktor reproduksi (B) NSK Indonesia S1 = Jawa Timur 1, S2 = Jawa Timur 2, S3 = Jawa Barat dan S4 = Jawa Tengah

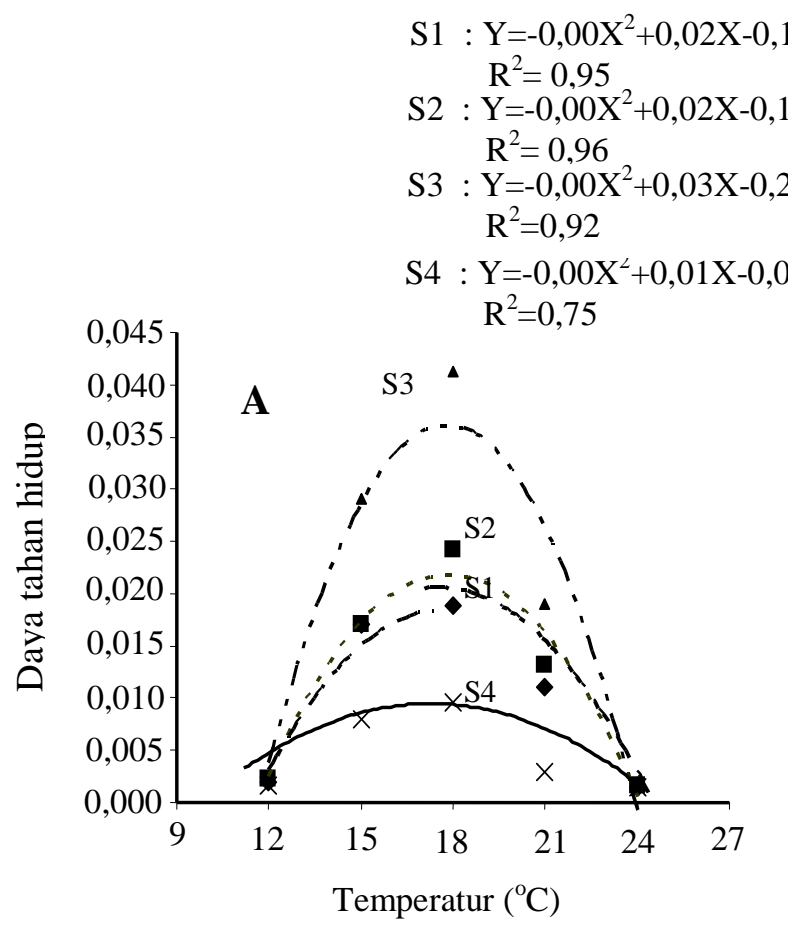

$$
0.16
$$

\section{6}




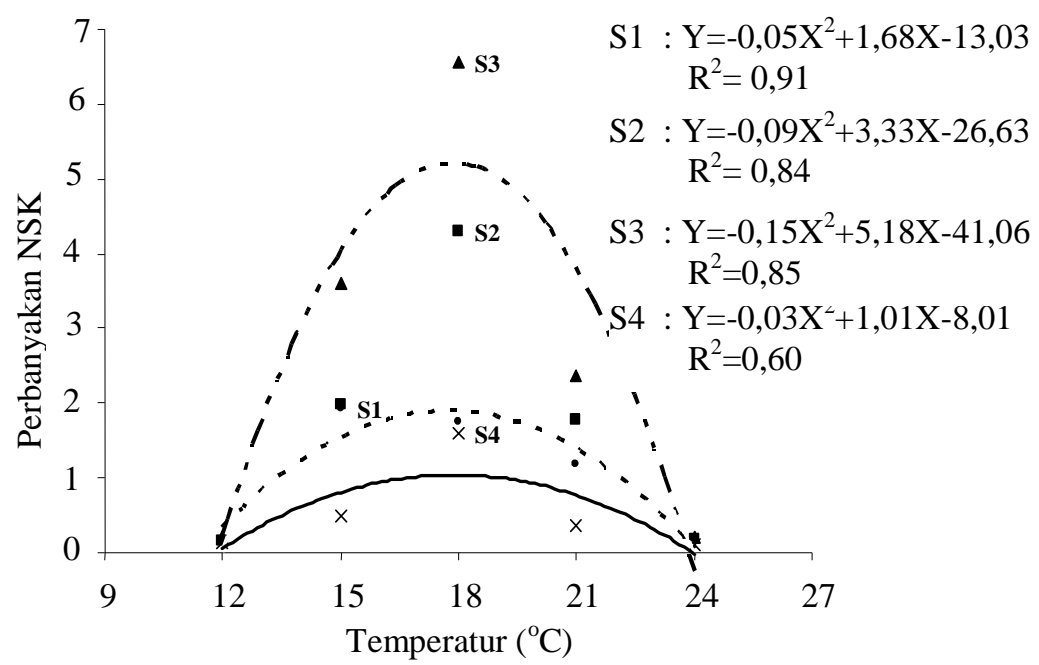

Gambar 3. Pengaruh temperatur terhadap perbanyakan NSK Indonesia S1 = Jawa Timur 1, S2 = Jawa Timur 2, S3 = Jawa Barat dan S4 = Jawa Tengah

optimum yang lebih rendah. Hasil ini juga sejalan dengan temperatur tanah yang didapat pada saat survei dilakukan. Pada lokasi survei di Jawa Timur rata-rata temperatur tanah adalah $19^{\circ} \mathrm{C}$, di Jawa Barat adalah $20^{\circ} \mathrm{C}$, sedangkan di Jawa Tengah rata-rata temperatur tanah lebih rendah, yaitu $16^{\circ} \mathrm{C}$.

Pada temperatur optimum sista dan telur nematoda menetas lebih cepat (Kuhn, 1972) sehingga nematoda yang menetap pada area dengan temperatur optimum bagi perkembangannya akan menyebabkan populasi nematoda tersebut lebih tinggi. Kondisi ini menyebabkan nematoda tersebut lebih dominan dibandingkan spesies lainnya (Robinson et al., 1987). Kehadiran kedua spesies NSK pada lokasi yang sama diduga dapat menyebabkan terjadinya kompetisi diantara kedua spesies tersebut. Oleh karena itu berdasarkan temperatur yang didapat memberi peluang bagi G. rostochiensis untuk mendominasi lokasi tersebut. Foot (1977) menyatakan walaupun pada suatu lokasi teridentifikasi kedua spesies NSK, temperatur akan menentukan satu spesies yang akan dominan di lokasi tersebut. Menurut Wharton (2004) setiap spesies mempunyai temperatur optimum yang berbeda untuk perkembangan dan aktivitas metabolismenya. Temperatur yang berada di bawah atau di atas temperatur optimum dapat menyebabkan laju dan aktivitas metabolisme menurun. Huang \& Pereira (1994) menyatakan temperatur juga mempengaruhi masa dormansi atau diapause nematoda yang selanjutnya akan mempengaruhi siklus hidup nematoda.

Hasil penelitian ini juga menunjukkan adanya korelasi positif yang sangat nyata antara faktor biologi yang diamati (Tabel 1). Hal ini menunjukkan adanya interaksi diantara faktor-faktor biologi tersebut, dengan kata lain setiap faktor biologi mempunyai ketergantungan yang sangat erat dengan faktor biologi yang lain. Menurut Patricia \& Keith (2004) tidak banyak laporan mengenai interaksi biologi ini, karena nematoda hidup di dalam tanah atau di dalam jaringan inang sehingga sulit untuk mengamatinya secara langsung.

\section{SIMPULAN}

Temperatur sangat mempengaruhi faktor biologi NSK, seperti jumlah sista baru, faktor reproduksi, daya tahan hidup, keperidian dan perbanyakan. Temperatur optimum untuk menghasilkan jumlah sista baru, faktor reproduksi, daya tahan hidup, keperidian dan perbanyakan yang optimum pada NSK populasi Jawa Timur 1, Jawa Timur 2, Jawa Barat dan Jawa Tengah adalah antara $15-21^{\circ} \mathrm{C}$. Jumlah sista baru, faktor reproduksi, daya tahan hidup, keperidian dan perbanyakan berkorelasi positif satu dengan yang lainnya. 
Tabel 1. Korelasi antara jumlah sista, faktor reproduksi, daya tahan hidup, keperidian dan perbanyakan NSK Indonesia

\begin{tabular}{ccccc}
\hline & Daya tahan hidup & Keperidian & Perbanyakan & Rf \\
\hline Keperidian & $0,29^{* *}$ & - & - & - \\
Perbanyakan & $0,91^{* *}$ & $0,48^{* *}$ & - & - \\
Rf & $1,00^{* *}$ & $0,30^{* *}$ & $0,91^{* *}$ & - \\
Jumlah sista & $1,00^{* *}$ & $0,29^{* *}$ & $0,91 * *$ & $1,00^{* *}$ \\
\hline
\end{tabular}

Keterangan : ** sangat nyata pada taraf $\alpha=1 \%$.

\section{DAFTAR PUSTAKA}

Castillo P \& Vovlas N. 2002. Factors affecting egg hatch of Heterodera mediterranea and differential responses of Olive cultivars to infestation. $J$. Nematology 34(2): 146-150.

Daryanto. 2003. Status penyebaran dan kerugian nematoda sista kentang pada tanaman kentang. Lokakarya Nematoda Sista Kentang 11-12 Desember 2003, Yogyakarta.

Ellis PR \& Hesling JJ. 1975. Larval emergence from cysts of twelve isolates of Heterodera rostochiensis and $H$. pallida reared on resistant and susceptible tomatoes. Plant Pathol. 24: 7783.

Ferris H, Eyre M, Venette RC \& Lau SS. 1996. Population energetics of bacterial feeding nematodes : stage-specific development and fecundity rates. Soil and Biochemis 28: 271-280.

Foot MA. 1977. Laboratory rearing of potato cyst nematode; a method suitable for pathotyping and biological studies. N.Z. J. Zool. 4: 183-186.

Foot MA. 1978. Temperature responses of three potato cyst nematode populations from New Zealand. Nematologica 24: 412-427.
Franco J. 1979. Effect of temperature on hatching and multiplication of potato cyst nematodes. Nematologica 25: 237-244.

Gao X \& Becker JO. 2002. Population development of both sexes of Heterodera schachtii is diminished in a beet cyst nematode-suppressive soil. Biol. Cont. 25: 187-194.

Huang SP \& Pereira AC. 1994. Influence of inoculums density, host, and low temperature period on delayed hatch of Meloidogyne javanica eggs. J. Nematology 26: 72-75.

Jensen HJ, Amstrong J \& Jatala P. 1979. Annotated bibliography of nematode pests of potato. Int. Potato Center, Lima, Peru.

Kuhn R. 1972. The hatching of larvae from cyst of the potato-root eelworm Heterodera rostochiensis and Heterodera sp. parasitizing Solanum tuberosum L. Pp. 111-135 In: Probleme der Phytonematologie. Vortrage Gross Lusewita. Juni 1972.

Lisnawita, Meity SS, Wattimena GA, Supramana \& Suastika G. 2005. Species identification of Indonesian potato cyst nematode using Polymerase Chain Reaction (PCR) technique. J.ISSAAS 11(3): 136-141 (Supplement). 
Mattjik AA \& Sumertajaya IM. 2000. Perancangan Percobaan : dengan aplikasi SAS dan Minitab Jilid I (Edisi kedua). Institut Pertanian Bogor Press, Bogor.

Mc Kenna LA \& Winslow RD. 1972. Differences in hatch and development rates of potato cyst nematode pathotypes. Ann. Appl. Biol. 71: 274278.

Mulder A. 1988. Temperature response of Globodera rostochiensis dan G. pallida (abstract). Nematologica 34: 281.

Noe JP. 1991. Development of Meloidogyne arenaria on peanut and soybean under two temperature cycle. J. Nematology 23: 468-478.

Patricia T \& Keith GD. 2004. Biotic Interactions. Pages 277-307 in : Randy G, Anwar LB, eds. Nematode Behaviour. CABI, New Jersey, USA.

Robinson MP, Atkinson HJ, Atkinson RN \& Perry RN. 1987. The influence of temperature on the hatching, activity and lipid utilization of second stage juveniles of the potato cyst nematodes Globodera rostochiensis and G. pallida. Revue Nematol. 10(3): 349-354.
Shepherd AM. 1985. Extraction and estimation of cyst nematodes. Pp. 31-49 In: Southey JF, eds. Laboratory Methods for Work with Plant and Soil Nematodes. Ministry of Agriculture, Fisheries \& Food, London.

Stone LEW \& Webley DP. 1975. The effect of heat on the hatch of potato cyst eelworms. Plant Pathol. 24:74-76.

Vannier G. 1994. The thermobiological limits of some freezing intolerant insects : the supercooling and thermostupor points. Acta Oecologica 15: 31-42 In: Gaugler R \& Bilgrami AL, eds. 2004. Nematode Behaviour. CAB International, UK.

Wharton DA. 2004. Survival Strategies. Pp. 371-399 In: Gaugler R \& Anwar LB, eds. Nematode Behaviour. CABI, New Jersey, USA.

Wharton DA, Goodall G \& Marshall. 2002. Freezing rate affects the survival of a short-term freezing stress in Panagrolaimus davidi, an Antartic nematode that survives intracellular freezing. CryoLetters 23: 5-10 In: Gaugler R \& Bilgrami AL, eds. 2004. Nematode Behaviour. CAB International, UK. . 